\title{
Dietary energy estimate inferred from fruit preferences of Cynopterus sphinx (Mammalia: Chiroptera: Pteropodidae) in a flight cage in tropical China
}

\author{
Aeshita Mukherjee ${ }^{1}$, Burkhard Wilske ${ }^{2} \&$ Jin $_{\text {Chen }}^{3}$ \\ ${ }^{1,3}$ Plant-Animal Interaction Group, ${ }^{2}$ Plant Physiological Ecology, \\ Xishuangbanna Tropical Botanical Garden, Chinese Academy of Sciences, Menglun, Mengla 666303, Yunnan, P.R. China \\ Email: ${ }^{1}$ aesh2003@yahoo.com
}

\begin{abstract}
From a conservation standpoint, inferences about dietary intake are much more robust when placed within a demographic, temporal and nutritional context. We investigated the dietary cornerstones of fruit preference and the dietary energy gained in the Short-nosed Fruit Bat Cynopterus sphinx. Feeding trials were conducted with 15 wild-caught bats kept in a large flight cage in Xishuangbanna, Yunnan, China, over nine weeks. The goal was to estimate the amount of food required for the sustenance of $C$. sphinx in captivity and calculate the food amount in terms of energy. Of the fruits (apple, banana, pear, papaya and guava) offered, apple $(89 \%)$ and banana $(93 \%)$ were found to be preferred. The relative consumption of fruit species tended to be positively correlated with the energy value per gram fruit. Banana (93\%) was the most preferred and papaya (47\%) the least preferred of the offered fruits. The results suggest that the minimum recommended dietary intake is $214-267 \mathrm{~kJ}$ per day for an individual of $C$. sphinx in captivity with conditions allowing flight. From this, we can assume that the same energy requirements may represent the minimum intake for bats in the wild. Both body mass and food consumption decreased significantly when bats were kept in a small cage.
\end{abstract}

Keywords: Body mass, captivity, Cynopterus sphinx, energy intake, fruit preference.

Date of publication (online): 26 June 2010 Date of publication (print): 26 June 2010 ISSN 0974-7907 (online) | 0974-7893 (print)

Editor: H. Raghuram

Manuscript details:

Ms \# 02326

Received 06 October 2009

Final revised received 04 April 2010

Finally accepted 24 April 2010

Citation: Mukherjee, A., B. Wilske \& J. Chen (2010). Dietary energy estimate inferred from fruit preferences of Cynopterus sphinx (Mammalia: Chiroptera: Pteropodidae) in a flight cage in tropical China. Journal of Threatened Taxa 2(6): 908-918.

Copyright: @ Aeshita Mukherjee, Burkhard Wilske \& Jin Chen 2010. Creative Commons Attribution 3.0 Unported License. JoTT allows unrestricted use of this article in any medium for non-profit purposes, reproduction and distribution by providing adequate credit to the authors and the source of publication.

Author Details, Author Contribution, Acknowledgements: See end of this article

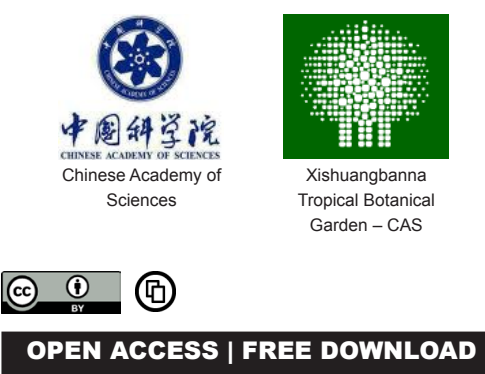

\section{INTRODUCTION}

Fruit bats play a crucial role in maintaining diversity in plant communities via regeneration and genetic flow of dominant forest trees (Banack 1996, 1998). Food resources like flowering and fruiting plants exert different selective forces on the foraging behaviour and energetic budgets of pollinators and the seed dispersers (Voigt et al. 2006). Fruit bats are important pollinators and seed dispersers in various ecosystems (Crome \& Irvine 1986; Eby 1991; Cox et al. 1991, 1992; Elmqvist et al. 1992; Findley 1993; Rainey et al. 1995; Banack 1996, 1998). Fruit bats may feed on a large number of different fruit species and substantial dietary information is available for some Pteropus species (Dobat \& Peikert-Holle 1985; Marshall 1985; Mickleburgh et al. 1992; Wiles \& Fujita 1992). However, few studies offer a thorough investigation of the energetics of fruit bats in a single area. Theories concerning diet breadth, diet selection and the evolution of feeding strategies in frugivorous bats have been based primarily on studies of neotropical fruit-eating bats (Phyllostomidae) along with support from African fruit-eating bats (Pteropodidae) (Fleming 1982, 1986). Fleming (1986) concluded that frugivorous bats eat a taxonomically nonrandom subset of fruits and seasonal availability of fruit is a key characteristic of the fruit taxa, which has allowed bats to specialize on them. A number of different physiological and behavioural strategies have been identified in mammals helping them to accommodate increased energy demands at various stages of their life cycle. These strategies include increases in energy intake (Brody 1945; Randolph et al. 1977; Millar 1978; Hickling et al. 1991) or mobilization of fat reserves to fuel the increased demands (Fedak \& Anderson 1982). Alternatively, the increased requirements at different stages can be offset by reduced physical activity (Randolph et al. 1977) or reduced maintenance energy expenditure of the mother during pregnancy (Speakman \& Racey 1987). It has been shown that lactating bats Myotis lucifugus and Eptesicus fuscus) and fruit-eating megachiropteran Rousettus aegyptiacus increases their field metabolic rate (Korine et al. 2004; Kurta et al. 1989a) 
where as the Plecotus auritus uses the compensatory strategies to offset increase energy demands (McLean \& Speakman 1999; Voigt 2000a). Daily activity is energetically costly, and may be the reason why during resting phase $S$. australis and other blossom-bats readily enter daily torpor to reduce metabolic rate (MR) even under mild environmental conditions (Bartholomew et al. 1970; Kulzer \& Storf 1980; Geiser et al. 1996; Coburn \& Geiser 1996, 1998; Bonaccorso \& McNab 1997; Bartels et al. 1998; Geiser 1998). Energy expenditure in the field can differ substantially from that predicted from basal metabolic rate (BMR) measurements in the laboratory (Geiser \& Coburn 1999).

As a group, bats have several characteristics unique among mammals with respect to their energy allocation and life histories. They are typified by having long life spans for their body sizes, and most species give birth to a single offspring followed by an extended parental care period (Kunz \& Pierson 1994). Moreover, pups do not begin foraging independently until they have nearly achieved adult size, possibly due to the constraints of flight (Barclay 1994).

Energy consumption and expenditure have been studied mainly in insectivorous free-ranging microchiropterans (Kunz 1974; Speakman \& Racey 1987; Kurta et al. 1989a,b, 1990; Kunz et al. 1995; Stern et al. 1997; McLean \& Speakman 1999; Reynolds \& Kunz 2000) and a few on fruit eating bats (Thomas 1984; Korine et al. 2004; Voigt et al. 2006). One may expect significant differences between the insectivorous microchiropterans and the frugivorous megachiropterans because of the latter's generally larger size and fruitbased diet. Proteins have sometimes been considered a limiting nutrient for frugivorous bats, as fruits are generally low in nitrogen (Thomas 1984; Courts 1998, Elangovan \& Marimuthu 2001). Thomas (1984) hypothesized that many frugivorous bat species over-ingest fruits to obtain sufficient protein with their diets. This may be the reason why many species of flying foxes also use flowers and leaves (Marshall 1985), as both flowers and leaves can contain substantial amounts of protein (Law 1992; Kunz \& Diaz 1995; Ruby et al. 2000). A number of dietary studies provide lists or tabulations of dietary items used by flying foxes, but quantifications of the amount of food intake are missing (e.g., Ratcliffe 1932; Funmilayo 1979; Dobat \& Peikert-Holle 1985; Marshall 1985; Richards 1990; Fujita 1991; Mickleburgh et al. 1992; Widmann 1996; Entwistle \& Corp 1997; Eby 1998). However, Elangovan \& Marimuthu (2001) reported the dietary intake and specifically the nitrogen content in the diet of C. sphinx. From a conservation standpoint, inferences about dietary intake are much more robust when placed within a demographic, temporal, and nutritional context.

We investigated the dietary cornerstones of (i) the food preference, and (ii) the respective energy gained based on results obtained with 15 wild-caught specimens of the Indian Short-nosed Fruit Bat (C. sphinx). C. sphinx feeds mainly on fleshy-pulpy fruits growing in and around the tropical rainforest, and also visits fruit orchards and exploit seasonally available fruits. This study aimed at (i) estimating the amount of food required for the sustenance of $C$. sphinx in captivity, and (ii) to calculate the food amount in terms of energy intake. In addition, we tested the hypothesis that of the above-mentioned three main strategies used by small mammals to cope with the energetic demands, C. sphinx would rather decrease food consumption in proportion to cage size. While the study estimates the food requirements to conserve or keep bats in captivity, the average dietary intake in captivity may also mark the minimum requirement of the species in the wild.

\section{METHODS}

\section{Bat collection and maintenance in captivity}

Eleven male and four female Indian Short-nosed Fruit Bats were mist netted in their natural habitats in and around Xishuangbanna Tropical Botanical Garden (21055.60'N \& $101^{0} 15.94$ 'E), in southern Yunnan Province, southwestern China. The bats $(n=15)$ were accommodated and kept in a newly set up flight cage for nine weeks. Thereafter the bats $(n=6)$ were individually housed for four weeks in small wire mesh cages, where their flights were confined to the cage. All bats were released at the end of the investigation.

Enclosure design and the captive environment govern a variety of behaviours that captive bats display (Heard 1998; Wilson 1988). Since bats are the only group of mammals that can truly fly, they need special attention as flight is severely limited in captivity (Wilson 1988). Greenhall (1976) suggested for experiments that cage sizes should be such that the bat can fly freely or not at all. For our study we used both a flight cage and subsequently a set of flight-restricting cages. The flight cage had a dimension of $10 \times 5 \times 2.5 \mathrm{~m}$, which allowed the bats to fly and dispose extra fat. The flight cage was set up under the canopy of a 50 year old rubber tree plantation to provide a mild climate and avoid extreme day and night temperatures. For the second set of feeding experiments, the bats were transferred to smaller wire-mesh cages (52 x $26 \times 30 \mathrm{~cm}$ ), which absolutely limited the flight option and made the bats more sedentary.

\section{Feeding trials}

To evaluate the food requirements, bats were kept in two different captive conditions and feeding trials were conducted over a period of two months in the flight cage and for one month in the flight restricted cage. The whole experiment was based on a natural fruit diet and the feeding trials were based on five different fruits. Of the five species of fruit, randomly three fruit species were display 
in 12 hanging food cups in different combination each day. To ensure fruit preference was unbiased, all possible combinations were tested for the five fruit species. Each fruit type was weighed separately using a digital balance (Scout ${ }^{\mathrm{TM}}$ Pro-balance, Ohaus Corporation, USA; precision of $0.5 \mathrm{~g}$ ) before given to the bats. The following evening the remaining fruits were collected separately by species in plastic bags, and weighed. Approximately $100 \mathrm{~g}$ fruit per bat were provided each day prior to sunset. Water was given ad libitum. Prior to the experiment, the fruits were cut into similar size and displayed to account for the water loss due to evaporation. We found negligible water loss due to very high humidity and tropical climate of the study area. The food preference was inferred from the difference between the amount of fruit offered and consumed. In order to verify a possible change in consumption, the amount of fruit displaced remained the same in both the captive conditions. The bats were retrapped and weighed to record the change in the body mass each weekend, which indirectly infers the estimated fat accumulation. Conversion from fruit intake to energy content and nutritional values were derived based on Smolin \& Grosvenor (1994) and compared with FAO (1995) as well as Centre for Food Safety Hong Kong (2006), The standard energy values per gram of fruits were taken and multiplied by the actual amount of food intake by the bats in our experiment. Following Duncan \& Young (2002) the selectivity index (S.I.) for each fruit type was calculated as

$$
\text { S.I. }=\frac{\left(1 / 3-P_{i}\right)^{2}+\left(1 / 3-P_{j}\right)^{2}+\left(1 / 3-P_{k}\right)^{2}}{2 / 3}
$$

where $P_{i}, P_{j}$ and $P_{k}$ are the proportions of the foods consumed per day.

\section{RESULTS}

\section{Fruit preference}

Three combinations of fruit offers including three to four different fruits were tested to examine food preferences in C. sphinx. Three Combined offers included both tropical fruits, which were available in abundance for the local bat population such as banana $(B)$, guava $(G)$, and papaya (PA), and fruits like apple (A) and pear (PE), which are not native and only available from few orchards within the region. From the combined offers of apple, banana, pear, and guava, the bats preferred apple and banana $\left(\chi^{2}\right.$ $=15.08$, $d f=3, p<0.05$ ) (and reconfirmed performing Wilcoxon signed ranks test, $z=2.275, p=0.028$ ). The selectivity index for apple was 0.43 , banana 0.39 , pear 0.13 , guava 0.11 and papaya 0.07 (Fig. 1). The same fruits were preferred when combined with papaya, and the preference for apple also dominated over guava and pear (two-tailed Mann-Whitney U-test, $\mathrm{U}=0, \mathrm{~N}_{1}=\mathrm{N}_{2}=$ $6, p<0.03)$. The offer of banana, apple and papaya in a percentage proportion of roughly 40:20:40 resulted in a predominant consumption of banana (two-tailed Wilcoxon signed-ranks test, $\mathrm{t}=0, \mathrm{~N}=10, \mathrm{p}<0.03$ ). Papayas yield the lowest preference (sign test; $\chi=1, N=10, p<0.04$ ) amongst both the native and uncommon fruits. The relative consumption of fruit species, i.e., (fruit $X$ consumed / fruit $X$ offered $)^{\star} 100$, tended to be positively correlated $(r=$ $0.82)$ with the caloric value per gram fruit (Fig. 2) based
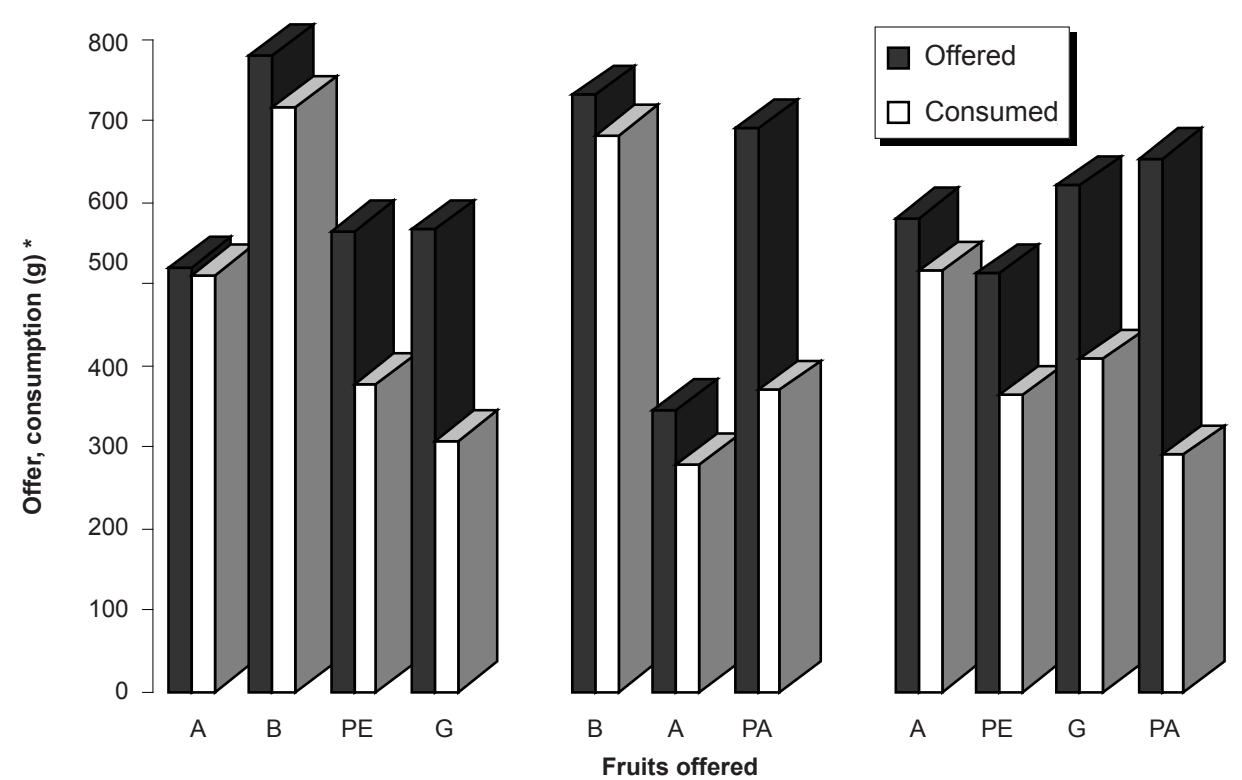

Figure 1. Fruit offer and fruit consumption of C. sphinx $(n=15)$ during two months in captivity.

* - Three combinations of five different fruit offered; A - Apple; B - Banana; PE - Pear; G - Guava; PA - Papaya 

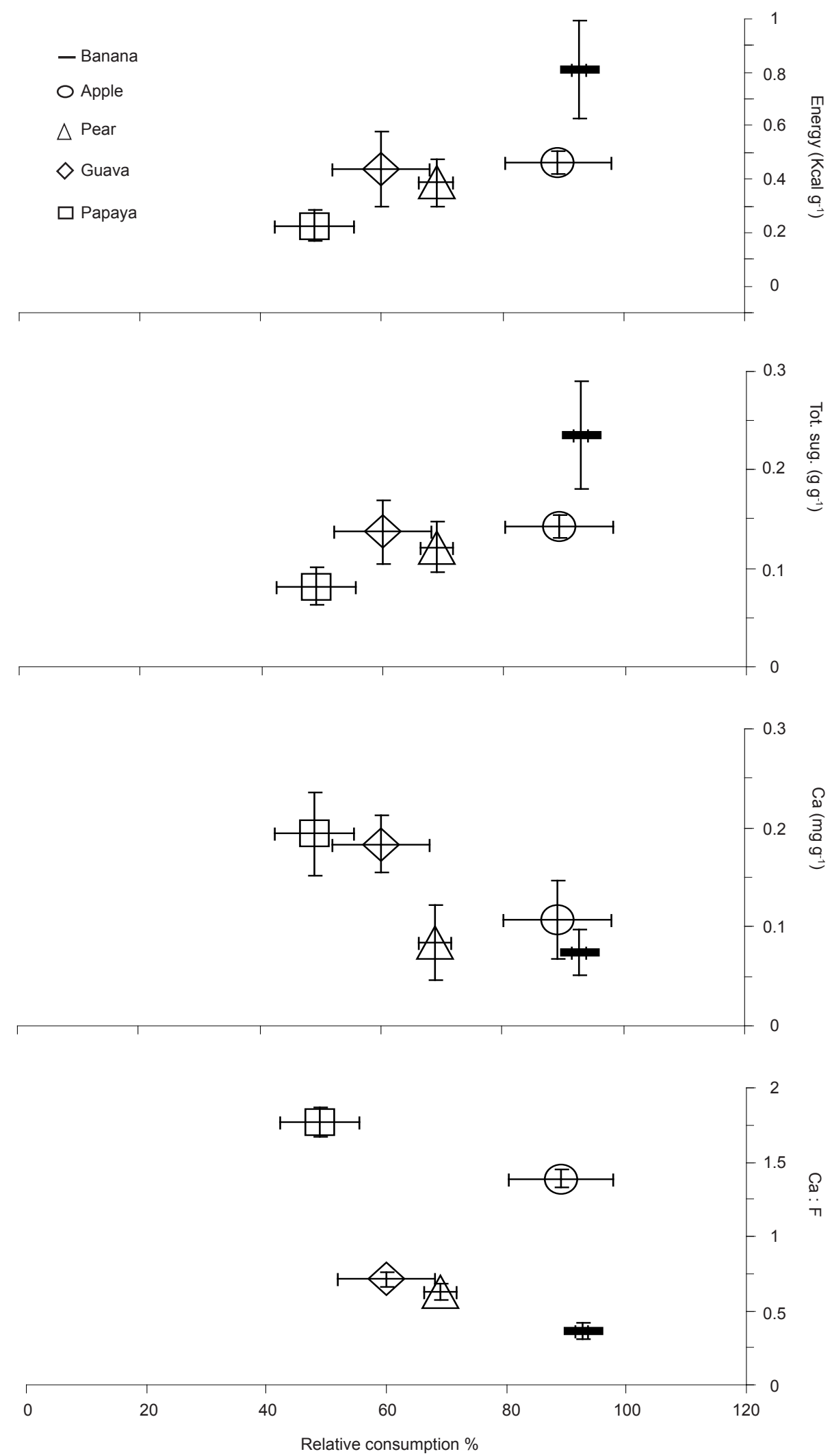

Figure 2. Nutritional values of fruit species versus the relative consumption by C. sphinx in captivity. Consumption of fruits shows the trend to correlate with both energy- and total sugar content. 
on averages derived from three independent sources (Smolin \& Grosvenor 1994; FAO 1995; Center for Food Safety Hong Kong 2006). Mainly apple escaped the trend. Contrasting, both the calcium content and the calcium-tophosphorus ratio were rather negatively correlated with the food preference of the bats during the experimental period (cold season).

\section{Fruit consumption}

The fruit consumption was significantly lower during the first two days compared to the rest of captive period $\left(\chi^{2}=21.5, \mathrm{df}=4, \mathrm{p}<0.05\right.$; Fig. 3$)$. The consumption was steady $(73-74 \%)$ and did not differ significantly during the initial five weeks (two-tailed Wilcoxon signed-ranked tests; $p>0.3$ ). The consumption showed an increment by

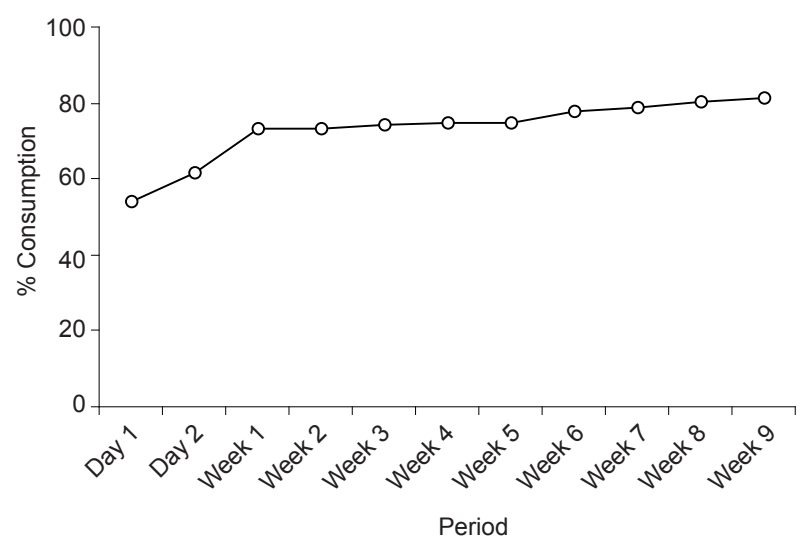

Figure 3. Pattern of food consumption by C. $\operatorname{sphinx}(\mathrm{n}=$ 15) over nine weeks of captivity.

Table 1. Nutritional value of average fruits consumed by $C$. sphinx in captivity

\begin{tabular}{|c|c|c|c|c|c|c|c|c|}
\hline Fruit consumption & & Unit & Banana & Apple & Pears & Guava & Papaya & Total fruit \\
\hline \multicolumn{9}{|l|}{15 bats / week } \\
\hline Weight & & $g$ & 3834.69 & 2801.29 & 780.25 & 586.09 & 1360.92 & 9363.25 \\
\hline \multicolumn{9}{|l|}{1 bat / day } \\
\hline Weight & & $\mathrm{g}$ & 36.52 & 26.68 & 7.43 & 5.58 & 12.96 & 89.17 \\
\hline Water & & $\%$ & 74.6 & 83.6 & 84.0 & 86.7 & 88.6 & \\
\hline \multirow[t]{3}{*}{ Energy } & [1] & Kcal & 26.30 & 13.61 & 3.27 & 3.85 & 4.15 & 51.17 \\
\hline & [2] & Kcal & 33.60 & 15.74 & 4.38 & 2.85 & 5.05 & 61.63 \\
\hline & [3] & Kcal & 39.81 & 15.47 & 3.20 & 2.29 & 3.50 & 64.26 \\
\hline Protein & & $\mathrm{g}$ & 0.32 & 0.00 & 0.04 & 0.06 & 0.09 & 0.51 \\
\hline \multirow[t]{3}{*}{ Carbohydrates } & [1] & $\mathrm{g}$ & 6.57 & 3.52 & 0.85 & 0.97 & 1.09 & 13.00 \\
\hline & [2] & $\mathrm{g}$ & 8.65 & 4.12 & 1.11 & 0.68 & 1.30 & 15.87 \\
\hline & {$[3]$} & $\mathrm{g}$ & 10.55 & 3.74 & 0.74 & 0.64 & 0.80 & 16.48 \\
\hline Fibers & & $\mathrm{g}$ & 0.61 & 0.58 & 0.19 & 0.33 & 0.12 & 1.84 \\
\hline Fat & & $\mathrm{g}$ & 0.38 & 0.02 & 0.04 & 0.07 & 0.01 & 0.53 \\
\hline Saccharides & & $\mathrm{g}$ & 0.03 & 0.02 & 0.01 & 0.02 & 0.01 & 0.10 \\
\hline \multirow[t]{3}{*}{$\mathrm{Ca}$} & [1] & $\mathrm{mg}$ & 3.65 & 2.67 & 0.74 & 0.84 & 2.20 & 10.10 \\
\hline & [2] & $\mathrm{mg}$ & 2.24 & 1.94 & 0.82 & 1.12 & 3.15 & 9.26 \\
\hline & [3] & $\mathrm{mg}$ & 2.19 & 4.00 & 0.30 & 1.12 & 2.20 & 9.81 \\
\hline \multirow[t]{3}{*}{$P$} & [1] & $\mathrm{mg}$ & 8.77 & 2.67 & 1.11 & 1.34 & 2.07 & 15.96 \\
\hline & [2] & $\mathrm{mg}$ & 7.05 & 1.94 & 0.82 & 1.43 & 0.65 & 11.88 \\
\hline & {$[3]$} & $\mathrm{mg}$ & 6.57 & 1.60 & 1.04 & 1.56 & 1.56 & 12.33 \\
\hline $\mathrm{Na}$ & & $\mathrm{mg}$ & 0.32 & 0.00 & 0.04 & 0.19 & 0.37 & 0.91 \\
\hline $\mathrm{K}$ & & $\mathrm{mg}$ & 144.48 & 30.56 & 9.29 & 15.88 & 33.24 & 233.44 \\
\hline $\mathrm{Zn}$ & & $\mathrm{mg}$ & 0.06 & 0.00 & 0.01 & 0.01 & 0.01 & 0.09 \\
\hline $\mathrm{Fe}$ & & $\mathrm{mg}$ & 0.13 & 0.05 & 0.02 & 0.02 & 0.01 & 0.22 \\
\hline $\mathrm{Mg}$ & & $\mathrm{mg}$ & 10.57 & 1.21 & 0.45 & 0.56 & 1.30 & 14.08 \\
\hline Vit A & & $\mathrm{RE}$ & 2.88 & 1.46 & 0.15 & 4.40 & 26.11 & 35.00 \\
\hline Vit C & & $\mathrm{mg}$ & 3.20 & 1.46 & 0.30 & 10.23 & 8.05 & 23.24 \\
\hline Vit B6 & & $\mathrm{mg}$ & 0.21 & 0.01 & 0.00 & 0.01 & 0.00 & 0.24 \\
\hline Folate & & micg & 7.05 & 0.73 & 0.56 & 0.81 & 4.91 & 14.05 \\
\hline Amino acids & & $\mathrm{mg}$ & 0.24 & 0.03 & 0.01 & 0.07 & 0.05 & 0.42 \\
\hline
\end{tabular}

[1] - FAO (1995); [2] - or without notation - Smolin \& Grosvenor (1994); [3] - Center for Food Safety Hong Kong (1997) 
$77 \%$ and reached up to $81 \%$ in the following weeks. We also found significant increase in food consumption per bat in relation to time between the two captive conditions (least square regression analysis: $p<0.01$; and $p<0.001$, respectively). Papaya (53\%) made the maximum portion of the left fruit.

Consumption of apple and banana ranked at par with $89 \%$ and $93 \%$, respectively. The consumption of fruits decreased significantly in the small cage $\left(\chi^{2}=32.8, \mathrm{df}=\right.$ $1, p<0.05$ and confirmed performing two-tailed Wilcoxon signed-ranks test, $\mathrm{t}=0, \mathrm{n}=8, \mathrm{p}<0.02$ ). Compared to the flight cage where the consumption ranged from $70-80 \%$ of the offered fruit, the same got reduced to $30-45 \%$ in the small cage. There was significant difference in fruit consumption when compared between flight cage and in the small cage (two way ANOVA, $F=5.43$, $d f=2, p<0.01$ ). The papaya made the bulk $(75 \%)$ of left out fruit. Unlike in the flight cage, where the consumption percentage increased over the period of captivity, in the small cage the consumption percentage showed a decreasing trend over a period of four weeks $(45.6,41.9,44.8,38.1 \& 30.3 \%$, respectively) (Fig. 3). Daily dietary intake and nutritional values. The average daily consumption of fruit per 15 bats was $400.18 \mathrm{~g}$ apple, $547.81 \mathrm{~g}$ banana, $83.72 \mathrm{~g}$ guava, $194.42 \mathrm{~g}$ pear, and $111.46 \mathrm{~g}$ papaya. Thus, the daily food consumption of food per bat was $36.52 \mathrm{~g}$ banana, $26.68 \mathrm{~g}$ apple, $7.43 \mathrm{~g}$ pear, $5.58 \mathrm{~g}$ guava, and $12.96 \mathrm{~g}$ papaya in the flight cage. The conversion and deduction of the total weekly fruit consumption of 15 bats to an individual bat per day equates to $269.03 \mathrm{~kJ}$ of energy that is required while in captivity based on the nutritional values obtained from Centre for Food Safety Hong Kong (2006), the same consumption deduced to only $214.27 \mathrm{~kJ}$ based on FAO 1995 values.

The water content of papaya $\left(0.88 \mathrm{~g} \mathrm{~g}^{-1}\right)$ is higher than for all the other fruits. Banana provides twice the amount of carbohydrate $\left(0.24 \mathrm{~g} \mathrm{~g}^{-1}\right)$ as compared to papaya (0.1 $\mathrm{g} \mathrm{g}^{-1}$ ). The comparison of fruits displaced in terms of energy gain, showed that banana and papaya provide the highest $\left(0.72-1.09 \mathrm{Kcal} \mathrm{g}^{-1}\right)$ and the least $(0.39-0.27 \mathrm{Kcal}$ $\left.\mathrm{g}^{-1}\right)$ amount of energy, respectively note that the lower and higher values were from FAO (1995) and Centre for Food Safety Hong Kong (2006), respectively.

To assimilate $69.03 \mathrm{~kJ}$, a bat needs to consume 200 $238 \mathrm{~g}$ of papaya but only 59-89 g of banana. Conversely, $200 \mathrm{~g}$ of papaya means that an average male bat would be required to consume more than four times its body weight per night. The amount of fruit consumed and the respective nutritional contents are given in Table 1.

\section{Comparisons of body mass changes}

The initial average body mass on catch was $48.4 \mathrm{~g}$ and $53.0 \mathrm{~g}$ for male and female, respectively. The average body mass decreased within the first two weeks after catch but later regained the weight of the original body mass. The female bats showed comparatively higher gain in body mass than the males (sign test; $x=1, n=10, p$ $<0.03$ ). The overall body mass did not differ significantly over the captive period of nine weeks (Fig. 4a). The average body mass of bats in the small cage showed a declining trend but was not significant (ANOVA \{time/ body mass $\}$ ): $p>0.05$ over the four-week experiment (Fig $4 b)$. With an average reduction from $55 \mathrm{~g}$ to $46 \mathrm{~g}$ and from $50 \mathrm{~g}$ to $46 \mathrm{~g}$ the females lost more weight than the males, respectively.

\section{DISCUSSION}

Cynopterus sphinx generally ate all fruits that were offered. However, large differences existed in the consumption relative to fruit species. Banana was the most preferred fruit followed by apple. Neither guava nor pear was consumed in the same amounts, and papaya was the least preferred of the fruits. While banana, papaya and guava are abundantly available throughout the area, both apple and pear represent introduced fruit. With caloric values of $0.27,0.41,0.43,0.58$ and 1.09 Kcal g-1, the five fruits papaya, guava, pear, apple and banana lined up along a positive trend of consumption increasing with the caloric value based on the nutritional values obtained from the Centre for Food Safety Hong Kong (2006). Even with deviating values for apple and pear, the nutritional contents published by Smolin \& Grosvenor (1994) corroborate the overall trend. FAO (1995) presented significantly lower $\left(0.72 \mathrm{Kcal} \mathrm{g}^{-1}\right)$ and higher $\left(0.69 \mathrm{Kcal} \mathrm{g}^{-1}\right)$ caloric values for Chinese banana and guava, respectively, which was reflected by giving a broader range of minimum energy requirement.

Still, a single fruit-related character such as energy content, abundance of resources or its exoticness may not fully explain the food preference of the bats. Few reports on food preference in bats include similar fruit. However, lowest preference for papaya was also reported for flying foxes (Banack 1998), which fed on papaya mainly during periods when alternative fruits where not available or not ripe. Contradictorily, the C. sphinx consumed/ preferred papaya over other fruits and banana was the least preferred fruits (Elangovan \& Marimuthu 2001).

The daily energy expenditure of the bats in captivity can be divided between the long roosting phase and a shorter activity phase when they fly around the food resources. It seems important to estimate the amount of energy bats need while in confinement. From the present study it appears that the daily intake of food varied according to their demand of energy expenditure for movement and during resting. The total consumption of fruit was significantly lower (roughly 30-40\%) for animals in flightrestrictive cages, reflecting less activity and hence lower energy requirements. Banack $(1996,1998)$ reported bats in the wild being extremely selective in choosing fruit within a tree, smelling and occasionally biting 10-15 

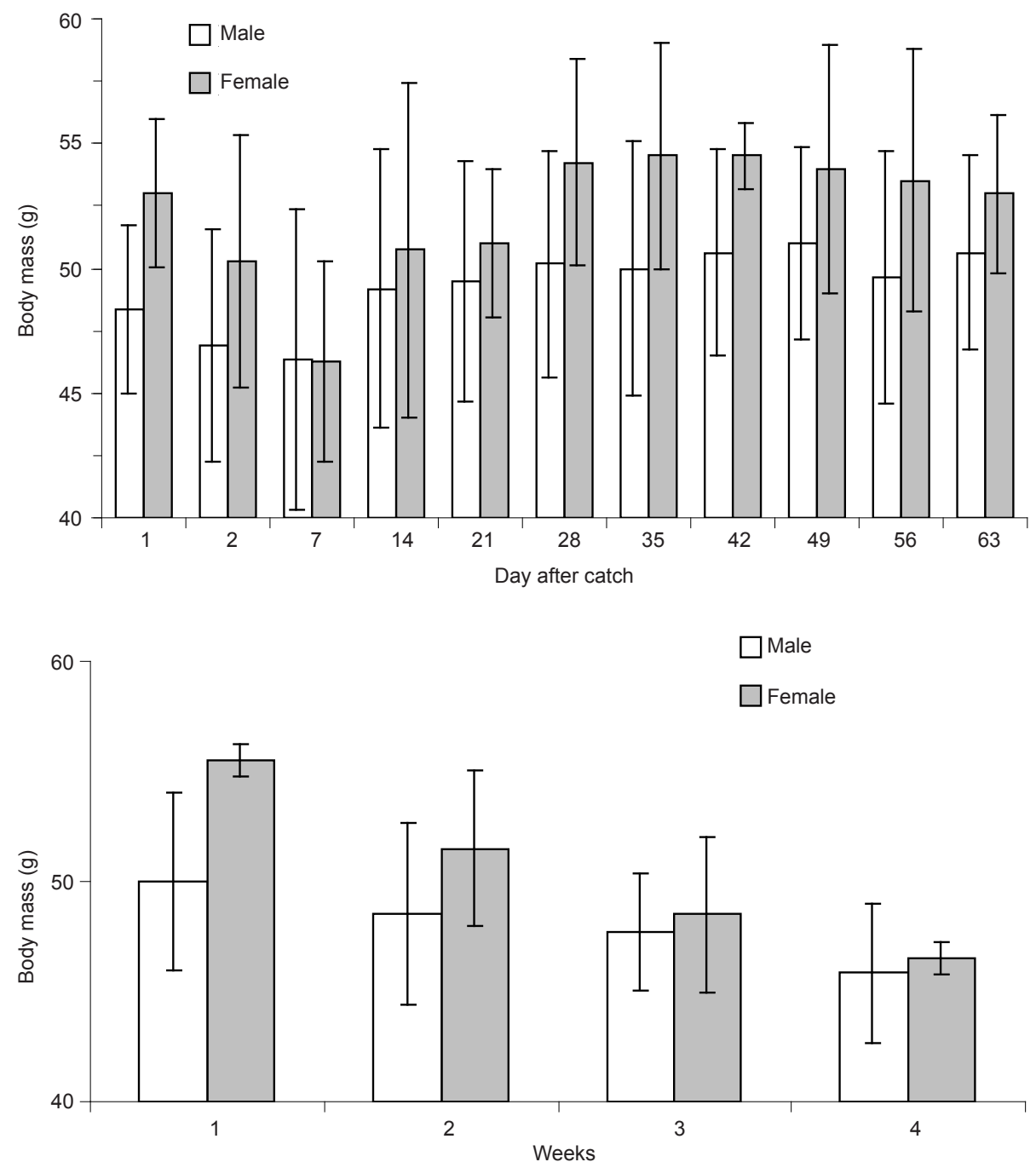

Figure 4a, b. Change in average body mass of $C$. sphinx: a). $(n=15)$ over a period of 63 days in a flight cage, b). $(n=6)$ over a period of four weeks in a small cage.

fruits before choosing one in situ or flying to another tree to continue the search. Such hyper-selective searching requires much higher energy input and may probably be less frequent under conditions of food scarcity.

In the flight cage, where the bats had to fly to get food, the individual bat consumed on average an energy equivalent to about $269 \mathrm{~kJ}$ (FAO 214.27kJ) per day. The validity of this value may underly some restrictions, because factors such as the environment and variations in both (seasonal) climate, handling-time efficiencies and physiological or morphological state can alter requirements in nutrients and secondary compounds (Rosenzweig \& Sterner 1970; Willson \& Harmeson 1973; Ellis et al. 1976; Pierson et al. 1996). The daily energy expenditure by blossom-bats in the laboratory is relatively high in winter, because they have long activity periods at night and undergo only short and shallow periods of torpor during the day (Coburn \& Geiser 1996, 1998). According to (Voigt 2000b, 2004; Voigt \& Winter 1999) the power requirements of horizontal forward flight are known to increase with body mass and thus mass-dependent costs of locomotion could substantially contribute to the overall higher energy expenditure of large individuals. Again, it is important to mention that the main phase of experiments was conducted during the month with lower temperatures, and hence in order to maintain homeostasis the bats may have used a higher proportion of energy even during resting. Furthermore, the daily energy intake averaged over both male and female and different ages, but did not reflect increased requirements due to pregnancy or lactation of female bats, which breed in area throughout the year (Mukherjee et al. 2006).

Despite differences in diet and feeding strategy among mammals, most species that have been studied appear to have similar qualitative nutrient needs for normal tissue metabolism. These similarities may also be true for fruit bats. Fruit bats presumably have no difficulty meeting energy needs during periods of food abundance because they consume large amounts of high carbohydrate fruits, both in captivity and in the wild. Analyses of most 
cultivated fruits indicate that the concentrations of many nutrients are quite low. Compared to established nutrient requirements of other mammals and the foods needed to provide them, fruit, when consumed alone, would seem to constitute an inadequate diet regarding their low protein content. However, several studies concluded that fruit bats could meet their protein requirements exclusively with fruits (Thomas 1984; Herbst 1986; Stellar 1986; Conklin-Brittain et al. 1999; Delorme \& Thomas 1999).

Occasional observations also revealed that some bats feed on leaves of some ficus species (A. Mukherjee pers. obs.; Korine et al. 1999; Nelson 2000). Pierson et al. (1996) reported that leaf resources may represent a regular part of the diet following major disturbances and during the breeding season.

Bats are one of the only other mammals besides humans that have problems with calcium deficiency, and reproduction by female bats may be limited by their intake of calcium. Nelson (2000) found that $83 \%$ of the captive bats engaged in leaf eating, and that $70 \%$ of female bats ate leaves, a particularly important calcium source. Bats may prefer high sugar containing and succulent fruits to relieve hypoglycaemia and dehydration. At least during the low-temperature months of our experiments the bats showed no particular preference for a special calcium-rich or a special $\mathrm{Ca} / \mathrm{P}$-ratio containing diet. However, such particular preferences may develop during other seasons and particularly during pregnancy. Furthermore, the way fruit bats eat, i.e., ingesting mostly juices and rejecting the fibrous portion of fruits, may result in higher bio-availability of the consumed calcium.

C. sphinx in our flight cage experiment behaved similar to wild-caught Short-tailed Fruit Bats (Carollia perspicillata), which reportedly rested for approximately 30 min between foraging bouts when the bats were kept in an outdoor enclosure (Bonaccorso \& Gush 1987). Shorttailed Fruit Bats have an extremely sensitive sense of smell (Laska 1990a) and are proficient at discriminating between similar odours (Laska 1990b) and olfaction is more important than either vision (Laska \& Schmidt 1986; Mikich et al. 2003) or echolocation (Theis et al. 1998) for the detection and gross location of food. C. sphinx appears to follow the same cue to locate food resources (Mukherjee et al. 2006). Again similar to the Short-tailed Fruit Bat, which showed the most diverse diet among several frugivorous bat species in Costa Rica (Fleming et al. 1977; Fleming 1988), C. sphinx showed preferences but otherwise consumed all the offered species of fruit. Based on our occasional observation over a period of three years while working in the rain forest, our study also suggests that $C$. sphinx is a dietary generalist (Table 2). Therefore, we have to assume that it must either use familiar food resources, which may be of low quality or ephemeral, or sample unknown and possibly toxic foods (Day et al. 2003; Ratcliffe et al. 2003) and might be operating on an overall tight energy budget (Delorme \&
Table 2. The plant exploited by C. sphinx in Xishuangbanna Tropical Botanical Garden

\begin{tabular}{|c|c|c|}
\hline Family & Species & Plant part \\
\hline Anacardiaceae & Mangifera indica & Fruit \\
\hline Euphorbiaceae & Sapium baccatum & Fruit \\
\hline \multirow[t]{11}{*}{ Moraceae } & Ficus hispida & Fruit \\
\hline & Ficus racemosa & Fruit \\
\hline & Ficus hederacea & Fruit \\
\hline & Ficus benjamina & Fruit \\
\hline & Ficus religiosa & Fruit + leaf \\
\hline & Morus macroura & Fruit \\
\hline & Ficus callosa & Fruit \\
\hline & Ficus ischnopoda Miq. & Fruit \\
\hline & Ficus tinctoria & Fruit \\
\hline & Ficus fistulosa & Fruit + leaf \\
\hline & ficus annulata & Fruit \\
\hline \multirow[t]{3}{*}{ Myrtaceae } & Psidium guajava & Fruit \\
\hline & $\begin{array}{l}\text { Syzygium oblatum (Roxb.) } \\
\text { Cowan (Wall.) }\end{array}$ & Fruit \\
\hline & $\begin{array}{l}\text { Syzygium fluviatile (Hemsl.) } \\
\text { Merr. et Perry }\end{array}$ & Fruit \\
\hline Rosaceae & Pygeum latifolium & Fruit \\
\hline \multirow[t]{4}{*}{ Sapindaceae } & Nephelium lappaceum & Fruit \\
\hline & Litchi chinwnsis & Fruit \\
\hline & Dimocarpus lognan & Fruit \\
\hline & Sapindus rarak & Leaf \\
\hline Sapotaceae & Achras sapota & Fruit \\
\hline Musaceae & Musa acuminata & $\begin{array}{l}\text { Fruit + } \\
\text { nectar }\end{array}$ \\
\hline Rubiaceae & Anthocephalus chinensis & Fruit \\
\hline Rhizophoraceae & Pellacalyx yunnanensis & Fruit \\
\hline Ebenaceae & Diospyros nigrocartex & Fruit \\
\hline Lauraceae & Beilschmiedia purpurascens & Leaf \\
\hline Flacourtiaceae & Flacourtia ramontchii L. Herit & Fruit \\
\hline Solanaceae & Solanum verbacifolium Linn. & Fruit \\
\hline
\end{tabular}

\section{Thomas 1996).}

Specific nutrient requirements for frugivorous bats remain virtually unknown, however, information exists providing practical guidelines to formulate diets for certain bat species in captivity. Research opportunities in bat nutrition proliferate, and regarding the bat species diversity, the information derived from a detailed diet plan for a large species would improve not only dietary husbandry of this species, but our understanding of the potential nutrient requirements of other species with similar dietary habits and feeding strategies.

Our study provides important information on food preferences and energy requirements for $C$. sphinx in captivity, and it may contribute to succesful captive breeding and conservation of the species. To improve diet 
formulas for fruit bats in long-term captivity, future research may put more focus on identifying the food combinations appropriate for meeting needs in micro-nutrients. It seems obvious that energy requirements for resting and for flight in captivity can be met by offering ad libitum quantities of nutritionally appropriate food, especially because fruit eating bats readily accept cultivated fruits. However, more detailed understanding of diets from bats in captivity also contributes to our understanding of bats in the wild.

\section{REFERENCES}

Banack, S.A. (1996). Diet selection and resource use by flying foxes, genus Pteropus, in the Samoan Islands: interactions with forest communities. PhD Thesis, University of California, Berkeley.

Banack, S.A. (1998). Diet selection and resource use by flying foxes. Ecology 79: 1949-1967.

Barclay, R.M.R. (1994). Constraints on reproduction by flying vertebrates - energy and calcium. American Naturalist 144 1021-1031.

Bartels, W., B.S. Law \& F. Gieser (1998). Daily torpor and energetics in a tropical mammal, the Northern Blossombat Macroglossus minimus (Megachiroptera). Journal of Comparative Physiology B 168: 233-239.

Bartholomew, G.A., W.R. Dawson \& R.C. Lasiewski (1970). Thermoregulation and heterothermy in some of the smaller flying foxes (Megachiroptera) of New Guinea. Zeitschrift Vergleichende Physiologie 70: 196-209

Bonaccorso, F.J. \& B.K. McNab (1997). Plasticity of energetics in blossom-bats (Pteropodidae): impact on distribution. Journal of Mammal 78: 1073-1088.

Bonaccorso, F.J. \& T.J. Gush (1987). Feeding behaviour and foraging strategies of captive phyllostomid fruit bats: an experimental study. Journal of Animal Ecology 56: 907-920.

Brody, S. (1945). Bioenergetics and growth. Hanfer, New York, USA.

Centre for food safety, Hong Kong (2007). Nutrient values of fruits and vegetables, Report No : 28, http://www.cfs.gov.hk, date of download: June, 2007

Coburn, D.K. \& F. Geiser (1998). Seasonal changes in energetics \&torpor patterns in the subtropical blossom-bat $S$ s. australis (Megachiroptera). Oecologia 113: 467-473.

Coburn, D.K. \& F. Geiser (1996). Daily torpor and energy savings in a subtropical blossom-bat, Syconycteris australis (Megachiroptera), pp.39-45, In: Geiser, F., A.J. Hulbert \& S.C. Nicol (eds.). Adaptations to The Cold. Tenth International Hibernation Symposium, University of New England Press, Armidale.

Conklin-Brittain, N.L., E.S. Dierenfeld, R.W. Wrangham, M. Norconk \& S.C. Silver (1999). Chemical protein analysis: a comparison of kjeldahl crude protein and total protein ninhydrin using wild, tropical vegetation. Journal of Chemical Ecology 25: 2601-2622.

Courts, S.E. (1998). Dietary strategies of old world fruit bats (Megachiroptera, Pteropodidae): how do they obtain sufficient protein? Mammal Review 28(4): 185-194.

Cox, P.A., T. Elmqvist, E.D. Pierson \& W.E. Rainey (1991). Flying foxes as strong interactors in South Pacific island ecosystems: a conservation hypothesis. Conservation Biology 5: 448-454.

Cox, P.A., T. Elmqvist, E.D. Pierson \& W.E. Rainey (1992). Flying foxes as pollinators and seed dispersers in Pacific island ecosystems, pp. 18-23. In: Wilson, D.E. \& G.L. Graham (eds.). Pacific Island Flying Foxes. Proceedings of the International Conservation Conference, USFWS Biol.
Report 90(23). U.S. Fish and Wildlife Service, Washington D.C., USA, $181 \mathrm{pp}$.

Crome, F.H.J. \& A.K. Irvine (1986). Two bob each way: the pollination and breeding system of the Australian rain forest tree Syzygium cormiflorum (Myrtaceae). Biotropica 18: 115125

Day, R.L., R.L. Coe, J.R. Kendal \& K.N. Laland (2003). Neophilia, innovation and social learning: a study of intergenic differences in callitrichid monkeys. Animal Behaviour 65: 559-571.

Delorme, M. \& D.W. Thomas (1996). Nitrogen and energy requirements of the Short-tailed Fruit Bat (Carollia perspicillata): fruit bats are not nitrogen constrained. Journal of Comparative Physiology B 166: 427-434.

Delorme, M. \& D.W. Thomas (1999). Comparative analysis of the digestive efficiency and nitrogen and energy requirements of the phyllostomid fruit bat (Artibeus jamaicensis) and the pteropid fruit bat (Rousettus aegyptiacus). Journal of Comparative Physiology B 169: 123-132.

Dobat, K. \& T. Peikert-Holle (1985). Blueten and Fledermaeuse. Verlag Waldemar Kramer, Frankfurt, Germany, 370pp.

Duncan, A.J. \& S.A. Young (2002). Can goats learn about foods through conditioned food aversions and preferences when multiple food options are simultaneously available? Journal of Animal Science 80: 2091-2098.

Eby, P. (1991). Seasonal movements of grey-headed flyingfoxes, Pteropus poliocephalus (Chiroptera: Pteropodidae), from two maternity camps in Northern New South Wales. Wildlife Research 18: 547-559.

Eby, P. (1998). An analysis of diet specialization in frugivorous Pteropus poliocephalus (Megachiroptera) in Australian subtropical rainforest. Australian Journal of Ecology 23: 443-456.

Elangovan, V. \& G. Marimuthu (2001). Comparative analysis on food, energy, and nitrogen intake of a megachiropteran bat, Cynopterus sphinx. Proceedings of the National Academy of Sciences, India. Vol. 71, BII: 115-120.

Ellis, J.E., J.A. Wiens, C.F. Rodell \& J.C. Anway (1976). A conceptual model of diet selection as an ecosystem process. Journal of Theoretical Biology 60: 93-108.

Elmqvist, T. , P.A. Cox, W.E. Rainey \& E.D. Pierson (1992). Restricted pollination on oceanic islands: pollination of Ceiba pentandra by flying foxes in Samoa. Biotropica 24: 15-23.

Entwistle, A.C. \& N. Crop (1997). The diet of Pteropus voeltzkowi, an endangered fruit bat endemic to Pemba Island, Tanzania. African Journal Ecology 35: 351-360.

FAO (1995). Nutritional values of tropical fruits and vegetables of southeast Asia. http://www.fao.org date of site visit: June, 2007.

Fedak, M.A. \& S.S. Anderson (1982). The energetics of lactation: accurate measurements from a large wild mammal, the Grey Seal (Halicboerus gryypus). Journal of Zoology (London) 198: 473-479.

Findley, J.S. (1993). Bats: A Community Perspective. Cambridge University Press, Cambridge, UK, 167pp.

Fleming, T.H. (1982). Foraging strategies of plant-visiting bats, pp.287-325. In: Kunz, T.H. (ed.). Ecology of Bats, Plenum, New York, USA.

Fleming, T.H. (1986). Opportunism versus specialization: the evolution of feeding strategies in frugivorous bats, pp. 105118. In: Estrada, A. \& T.H. Fleming (eds.). Frugivores and Seed Dispersal. Dr. W. Junk, Dordrecht, NL.

Fleming, T.H. (1988). Evolution and ecology of phyllostomid bats, pp.3-35. In: Schaller, G.B. (ed.). The Short-tailed Fruit Bat: A Study in Plant-Animal Interactions. University of Chicago Press, Chicago, Illinois, USA.

Fleming, T.H., E.R. Heithaus \& W.B. Sawyer (1977). An experimental analysis of the food location behavior of frugivorous bats. Ecology 58: 619-627. 
Fujita, M. \& M.D. Tuttle (1991). Flying foxes (Chiroptera Pteropodidae): threatened animals of key ecological and economic importance. Conservation Biology 5: 455-463.

Funmilayo, O. (1979) Ecology of the straw-coloured fruit bat in Nigeria. Revue de Zoology Africaine 93: 589-600.

Geiser, F. (1998). Cool bats. Nature Australia 26: 56-63.

Geiser, F. \& D.K. Coburn (1999). Field metabolic rates and water uptake in the blossom-bat Syconycteris australis (Megachiroptera). Journal of Comparative Physiology B 169: 133-138.

Geiser, F., D.K. Coburn, G. Koertner \& B.S. Law (1996). Thermoregulation, energy metabolism, and torpor in blossom-bats, Syconycteris australis (Megachiroptera). Journal of Zoology (London) 239: 583-590.

Greenhall, A.M. (1976). Care in captivity. Pp. 89-131, in Biology of Bats of the New World Family Phyllostomatidae. Part I. (R. J. Baker, J. K. Jones, and D. C. Carter, eds.). Spec. Publ. Mus. Texas Tech. Univ., Lubbock, Texas, USA.

Heard, D.J. (1998). Chiroptera: Medical Management of Megachiropterans, pp.344-354. In: Fowler. M.E. \& R.E. Miller (eds.). Zoo and Wild Animal Medicine. Current Therapy 4. W.B. Saunders, Philadelphia, London.

Herbst, L.H. (1986). The role of nitrogen from fruit pulp in the nutrition of the frugivorous bat Carollia perspicillata. Biotropica 18: 39-44.

Hickling, G.J., J.S. Millar \& R.A. Moses (1991). Reproduction and nutrient reserves of the bushy-tailed wood rats (Neotoma cinerea). Canadian Journal of Zoology 69: 3088-3092.

Korine, C., I. Izhaki \& Z. Arad (1999). Is the Egyptian Fruit-bat, Rousettus aegyptiacus a pest in Israel? An analysis of the bat's diet and the implication for its conservation biology. Biological Conservation 88: 301-306.

Korine, C., J. Speakman \& Z. Arad (2004). Reproductive energetics of captive and free ranging Egyptian Fruit Bats (Rousettus aegyptiacus). Ecology 85: 220-230.

Kulzer, E. \& R. Storf (1980). Schlaf-Lethargie bei dem afrikanischen Langzungenflughund Megaloglossus woermanni Pagenstecher, 1885. Zeitschrift fuer Saeugetierkunde 45: 23-29.

Kunz, T.H. (1974). Feeding ecology of a temperate insectivorous bat (Myotis velifer). Ecology 55: 693-711.

Kunz, T.H. \& E.D. Pierson (1994). Bats of the world: an introduction, pp.1-46. In: Nowak, R.W. (ed.). Walker's Bats of The World. Johns Hopkins University Press, Baltimore, Maryland, USA, 287pp.

Kunz, T.H., J.O. Whitaker, Jr. \& M.D. Wadanoli (1995). Dietary energetics of the insectivorous Mexican Free-tailed Bat (Tadarida brasilliensis) during pregnancy and lactation. Oecologia 101: 407-415

Kunz, T.H. \& C.A. Diaz (1995). Folivory in fruit-eating bats, with new evidence from Artibeus jamaicensis (Chiroptera: Phyllostomidae). Biotropica 27: 106-120.

Kurta, A., G.P. Bell, K.A. Nagy \& T.H. Kunz (1989a). Energetics of pregnancy and lactation in free-ranging Little Brown Bats (Myotis lucifugus). Physiological Zoology 62: 804-818.

Kurta, A., G.P. Bell, K.A. Nagy \& T.H. Kunz (1989b). Water balance of free-ranging Little Brown Bats (Myotis lucifugus) during pregnancy and lactation. Canadian Journal of Zoology 67: 2468-2472.

Kurta, A., T.H. Kunz \& K.A. Nagy (1990). Energetics and water flux of free-ranging Big Brown Bats (Eptesicus fuscus) during pregnancy and lactation. Journal of Mammalogy 71: 59-65.

Laska, M. \& U. Schmidt (1986). Olfactory orientation in Carollia perspicillata (Chiroptera). Zeitschrift Saeugetierkunde 51: 129-138.

Laska, M. (1990a). Olfactory sensitivity to food odor components in the Short-tailed Fruit Bat, Carollia perspicillata (Phyllostomidae, Chiroptera). Journal of Comparative Physiology A 166: 395-399.
Laska, M. (1990b). Olfactory discrimination ability in the Shorttailed Bat, C. perspicillata (Chiroptera:Phyllostomidae). Journal of Chemical Ecology 16: 3291-3299.

Law, B.S. (1992). The maintenance nitrogen requirements of the Queensland blossom bat (Syconycteris australis) on a sugar/ pollen diet: is nitrogen a limiting resource? Physiological Zoology 65: 634-648.

Marshall, A.G. (1985). Old world phytophagous bats (Megachiroptera) and their food plants: a survey. Biological Journal of the Linnean Society 83: 351-369.

McLean, J.A. \& J.R. Speakman (1999). Daily energy budgets of lactating female Brown Long-eared Bats (Plecotus auritus) suggest they use compensation during lactation. Functional Ecology 13: 360-372.

Mickleburgh, S.P., A.M. Huston \& P.A. Racey (1992). Old World Fruit Bats. An Action Plan for Their Conservation. International Union for Conservation of Nature and Natural Resources. (IUCN/SSC) Chiroptera Specialist Group, Gland, $\mathrm{CH}, 252 \mathrm{pp}$.

Mikich, S.B., G.V. Bianconi, B.H.L.N.S. Maia \& S.I. Teixeira (2003). Attraction of the fruit-eating bat Carollia perspicillata to Piper gaudichaudianum essential oil. Journal of Chemical Ecology 29: 2379-2383.

Millar, J.S. (1978). Energetics of reproduction in Peromyscus leucopus: the cost of lactation. Ecology 59: 1055-1061.

Mukherjee, A., Z.H. Tang \& J. Chen (2006). Occurrence and morphometric variability in the frugivorous bat species Cynopterus sphinx and Rousettus leschenaultifrom a tropical rain forest, Xishuangbanna, SW-China. Acta Chiropterologica 8(2): 417-427.

Nelson, S.L., M.A. Miller, E.J. Heske \& G.C. Fahey Jr. (2000). Nutritional quality of leaves and unripe fruit consumed as famine foods by the flying foxes of Samoa. Pacific Sciences 54: 301-311.

Pierson, E.D., T. Elmqvist, W.E. Rainey \& P.A. Cox (1996). Effects of tropical cyclone storms on flying fox populations on the South Pacific Islands of Samoa. Conservation Biology 10: 438-451.

Rainey, W.E., E.D. Pierson, T. Elmqvist \& P.A. Cox (1995). The role of flying foxes (Pterododidae) in oceanic island ecosystems of Pacific. Zoology Symposium 67: 47-62.

Randolph, P.A., J.C. Randolph, K. Mattingly \& M.M. Foster (1977). Energy costs of reproduction in the Cotton Rat, Sigmodon bispidus. Ecology 58: 31-45.

Ratcliffe, F.N. (1932). Notes on the fruit bats (Pteropus spp.) of Australia. Journal of Animal Ecology 1: 32-57.

Ratcliffe, J.M., M.B. Fenton \& B.G. Galef Jr. (2003). An exception to the rule: common vampire bats do not learn taste aversions. Animal Behaviour 65: 385-389.

Reynolds, D.S. \& T.H. Kunz (2000). Changes in body composition during reproduction and postnatal growth in the Little Brown Bat, Myotis lucifugus (Chiroptera: Vespertilionidae). Ecoscience 7: 10-17.

Richards, G.C. (1990). The Spectacled Flying-fox, Pteropus conspicillatus (Chiroptera: Pteropodidae), in north Queensland. 2. Diet, seed dispersal and feeding ecology. Australian Mammalogy 13: 25-31.

Rosenzweig, M.L. \& P.W. Sterner (1970). Population ecology of desert rodent communities: body size and seed-husking as bases for Heteromyid coexistence. Ecology 51: 217-224.

Ruby, J., P.T. Nathan, J. Balasingh \& T.H. Kunz (2000). Chemical composition of fruits and leaves eaten by Shortnosed Fruit Bat, Cynopterus sphinx. Journal of Chemical Ecology 26: 2825-2841.

Smolin, L.A. \& M.M. Grosvenor (1994). Nutrition - Science and Applications. Saunders College Publisher, Philadelphia, USA $576 \mathrm{pp}$.

Speakman, J.R. \& P.A. Racey (1987). The energetics of pregnancy and lactation in the brown long-eared bats 
(Plecotus auritus), pp.367-394. In: Fenton, M.B., P.A. Racey \& J.M.V. Rayner (eds.). Recent Advances in the Study of Bats. Cambridge University Press, Cambridge, UK, 470pp.

Stellar, D.C. (1986). The dietary energy and nitrogen requirements of the Grey-headed Flying Fox Pteropus poliocephalus (Megachiroptera). Australian Journal of Zoology 34: 339-349.

Stern, A.A., T.H. Kunz, E.H. Studier \& O.T. Oftedal (1997). Milk composition and lactation output in the Greater Spear-nosed Bat, Phyllostomus hastatus. Journal of Comparative Physiology B 167: 389-398.

Thies, W., E.K.V. Kalko \& H.U. Schnitzler (1998). The roles of echolocation and olfaction in two Neotropical fruit-eating bats, Carollia perspicillata and C. castanea, feeding on piper. Behavioral Ecology and Sociobiology 42: 397-409.

Thomas, D.W. (1984). Fruit intake and energy budgets of frugivorous bats. Physiological Zoology 57: 457-467.

Voigt, C.C. (2000a). Reproductive energetics of the nectar-feeding bat Glossophaga soricina (Phyllostomidae). Journal of Comparative Physiology B 173: 79-85.

Voigt, C.C. (2000b). Intra-specific scaling of flight costs in Glossophaga soricina (Phyllostomidae, Glossophaginae). Journal of Comparative Physiology B 170: 403-410.

Voigt, C.C. (2004). The power requirements in the nectar-feeding bat Glossophaga soricina (Phyllostomidae, Glossophaginae) for clinging to flowers. Journal of Comparative Physiology B 174: 541-548.

Voigt, C.C \& Y. Winter (1999). The energetic costs of hovering flight in glossophagine bats (Phyllostomidae: Glossophaginae) and its scaling in bats, hummingbirds and moths. Journal of Comparative Physiology B 169: 38-48.

Voigt, C.C., H. Detlev, G. Kelm \& H. Visser (2006). Field metabolic rates of phytophagous bats: do pollination strategies of plants make life of nectar-feeders spin faster? Journal of Comparative Physiology B 176: 213-222.

Widmann, P. (1996). Importance of fruit bats for pollination and seed dispersal in orchards and forests in Leyte, Philippines. Deutsche Gesellschaft f. Technische Zusammenarbeit, Eschborn, Germany.

Wiles, G.J. \& M. Fujita (1992). Food plants and economic importance of flying foxes on Pacific Islands, pp.2435. In: Pacific island flying foxes. Wilson, D.E. \& G.L. Graham (eds.). Proceedings of an International Conservation Conference. USFWS Biological Report 90(23). United States Fish and Wildlife Service, Washington D.C., USA.

Willson, M.F. \& J.C. Harmeson (1973). Seed preferences and digestive efficiency of cardinals and song sparrows. Condor 75: 225-234.

Wilson, D.E. (1988). Maintaining bats for captive studies, pp.247-264. In: Kunz, T.H. (ed.). Ecological and Behavioral Methods for the Study of Bats. Smithsonian Institution Press, Washington D.C.
Author Details: Dr. Aeshita Mukherjee is an ecologist and was a Postdoctoral Fellow with the Plant-Animal Interaction Group, Xishuangbanna Tropical Botanical Garden, Chinese Academy of Sciences, P.R. China. Dr. BuRkHARD WILSKE is an ecophysiologist, Botanist having expertise in $\mathrm{VOC}$ and Carbon budgeting. He is presently a Postdoctoral Fellow at the Bio-Geosciences Institute, University of Calgary, Canada. PRoF. CHEN JIN is the Director of Xishuangbanna Tropical Botanical Garden, Chinese Academy of Sciences, P.R. China.

Author Contribution: The first author AM designed the research plan, data collection, analysis and wrote this manuscript, while the second author BW's input was interpretation of result, literature search and helping in analysis. The third author JC provided guidance and was the over all project in-charge.

Acknowledgements: The findings are an outcome of a postdoctoral study supported by the XTBG, Chinese Academy of Sciences. We are thankful to the Chinese Academy of Sciences for the technical and financial support during the study. We also thank the Forest Department, Yunnan Prefecture, and the XTBG officials for allowing us to perform both wild and captive studies on fruit bats. We are grateful to Mr. Shao Li, and Mr. Swat Sanjitan, Plant animal Interaction Group, XTBG, CAS, for ready help, field assistance and in smooth conduct of these experiments. 